\title{
Characterization of active layer water contents in the McMurdo Sound region, Antarctica
}

\author{
C.A. SEYBOLD ${ }^{1}$, M.R. BALKS ${ }^{2}$ and D.S. HARMS ${ }^{1}$ \\ ${ }^{1}$ USDA-NRCS, National Soil Survey Center, 100 Centennial Mall North, Federal Building, Rm. 152, Lincoln, NE 68508-3866, USA \\ ${ }^{2}$ Earth \& Ocean Sciences, University of Waikato, Private Bag 3102, Hamilton, New Zealand \\ cathy.seybold@lin.usda.gov
}

\begin{abstract}
The liquid soil water contents in the seasonally thawed layer (active layer) were characterized from seven soil climate monitoring sites - four coastal sites from south to north (Minna Bluff, Scott Base, Marble Point and Granite Harbour), and inland sites from low to high altitude (Wright Valley, Victoria Valley and Mount Fleming). Mean water contents ranged from $0.013 \mathrm{~m}^{3} \mathrm{~m}^{-3}$ near the surface at Victoria Valley to $0.33 \mathrm{~m}^{3} \mathrm{~m}^{-3}$ near the ice-cemented layer at Granite Harbour. The coastal sites have greater soil water contents than the McMurdo Dry Valley and Mount Fleming sites, and moisture contents increase with depth in the active layer. The Wright Valley site receives very little infiltration from snowmelt, with none in most years. All other sites, except Mount Fleming, received between one and four wetting events per summer, and infiltrated water moved to greater depths $(\approx 10-25 \mathrm{~cm})$. The Scott Base and Granite Harbour sites are on sloping ground and receive a subsurface flow of water along the ice-cemented permafrost. Our findings indicate that water contents are low with very little recharge, are greatly influenced by the local microclimate and topography, and show no significant increasing or decreasing trend over 10 years of monitoring.
\end{abstract}

Received 26 March 2010, accepted 8 August 2010

Key words: active layer, Antarctic soil, Cryosol, Dry Valleys, Gelisols, soil moisture

\section{Introduction}

Soil water controls plant growth and influences a variety of soil processes including erosion, chemical exchange, microbial activity, transport of solutes and water, and pedogenesis. In the ice-free areas of Antarctica the duration and amount of available moisture is a crucial factor restricting the presence, abundance, and diversity of terrestrial biota (Cameron \& Conrow 1969). Antarctic ecosystem processes depend upon the proximity of water and the duration of liquid water availability (Barrett et al. 2006) and it is important to understand soil moisture and water regimes in Antarctica's cold desert environment because of possible links to climate change. The fate of ground ice is affected by the amount and distribution of liquid water infiltrating the soil (Hagedorn et al. 2010). Soil water availability and moisture recharge in Antarctic soils is dependent on whether snow and ice melts or sublimates. Modelling has shown that in the valley bottoms, sublimation far exceeds precipitation, and the amount of moisture that enters the ground is unclear because it sublimates prior to melting (Fountain et al. 2009). Thus, there is a need to characterize the average and dynamic changes in soil water contents of Antarctic soils.

Soil moisture and water holding capacity information for the soils in the McMurdo Sound region is limited (Balks et al. 2002). Soil field moisture contents ranged from $1-5 \%$ (by weight) in the upper $10 \mathrm{~cm}$ for soils at Marble Point, Wright Valley, and Scott Base (Balks et al. 2002).
At undisturbed sites at Marble Point, soil moisture ranged from $0.5-10 \%$ (by weight) within the active layer (Campbell et al. 1994). Campbell et al. (1997) reported moisture contents in the active layer of about 5\% (by weight) which diminished to about $1 \%$ or less on the Dry Valley floors and sides. Gooseff et al. (2003) reported soil moisture values under snow patches in the Dry Valleys that ranged from $6.9-13.6 \%$ (by weight) compared to $0.4 \%$ (by weight) in bare soil.

The objectives of this study are to characterize the liquid soil water contents in the seasonally thawed layer (active layer) from a range of soil climate monitoring sites in the McMurdo Sound region. This paper contributes to the Latitudinal Gradient Project "Key Question 4: How does climate affect the availability and composition of free water?" by providing a benchmark soil moisture characterization for the mid-section of the latitudinal gradient range.

\section{Materials and methods}

Seven soil climate stations (SCS) were established in the Ross Sea region of Antarctica. Two of the stations are in the McMurdo Dry Valleys, four border the Antarctic coast, and one is on Mount Fleming at the head of the Wright Valley (Fig. 1, Table I). The stations were established at Wright Valley, Victoria Valley, Marble Point, and Scott Base in January 1999, Mount Fleming in January 2002, and at Granite Harbour and Minna Bluff in January 2003. 


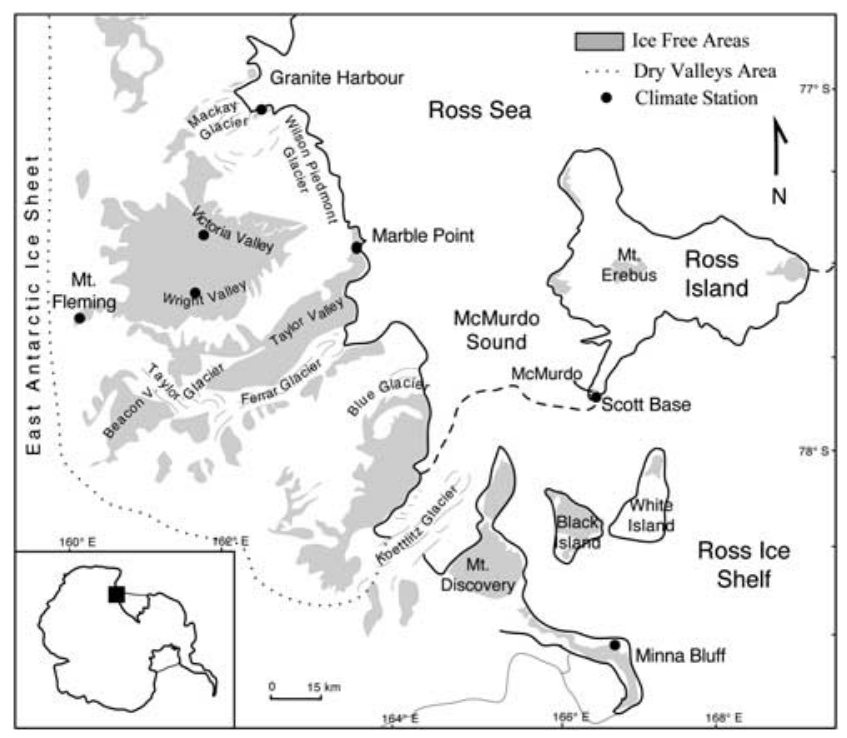

Fig. 1. Map of the McMurdo Sound region showing locations of the seven soil climate stations.

The Wright Valley SCS is located on the foot slope of an outwash terrace below Bull Pass. The site is on a colluvial fan derived from strongly weathered glacial till that is dominated by granodiorite with some diorite and other lithologies. The Victoria Valley site is in a former lake bed characterized by low-centred polygons on alluvial deposits (Hagedorn et al. 2007) that are dominated by granite with some marble and sandstone. Marble Point is a coastal station by the Ross Sea and is located on the nose slope of a fluvial terrace composed of weakly weathered glacial till dominated by gneiss and granite. The Scott Base site is on Ross Island, uphill from Scott Base, on a side-slope of scoriaceous basalt with minor inputs of glacially derived gravel and sand of mixed lithology. The Minna Bluff SCS is adjacent to the Ross Ice Shelf, and is located on patterned ground, which formed in ablation till that is dominated by basalt and granite rock fragments. The northernmost coastal station is Granite Harbour, located on a narrow (c. $60 \mathrm{~m}$ wide) fan/lateral moraine (dominated by granite rock materials) between a cliff-face and the edge of sea ice. Between the rocks is sand that may have been reworked by marine and glacial processes. The Mount Fleming SCS is located on patterned ground within a cirque, on the north side of Mount Fleming. The parent material is glacial till of mixed lithology that is dominated by dolerite, but sandstone and granite are common. Adlam et al. (2010) provides additional information on the sites.

Soils pits were dug, by hand, at each site. The soil morphology on one of the pit faces was described and horizons sampled for chemical and physical characterization at the United States Department of Agriculture-Natural Resources Conservation Service (USDA-NRCS), National Soil Survey Center in Lincoln, Nebraska, USA. Soil descriptions are in Appendix A. Soil samples were air-dried $\left(30-35^{\circ} \mathrm{C}\right)$ and sieved $(<2 \mathrm{~mm})$. The $>2 \mathrm{~mm}$ fragments were sieved to determine the $2-5 \mathrm{~mm}$ and $5-20 \mathrm{~mm}$ fractions. The $20-75 \mathrm{~mm}$ fraction was measured, and the $>75 \mathrm{~mm}$ volume fraction was visually estimated in the field. A portion of the bulk sample was set aside to determine bulk density $(<75 \mathrm{~mm}$ fraction) by repacking cores of air-dried sample. Average bulk densities of similar textured soil in the USDA-NRCS characterization database were used as an estimate of the bulk density

Table I. Location of the seven soil climate stations and soil classifications.

\begin{tabular}{|c|c|c|c|c|c|c|}
\hline Site & Location & $\begin{array}{c}\text { Elevation } \\
\mathrm{m}\end{array}$ & $\begin{array}{c}\text { Average } \\
\text { maximum } \\
\text { active layer } \\
\text { depth }(\mathrm{cm})^{+}\end{array}$ & $\begin{array}{l}\text { Depth to ice- } \\
\text { cemented ground } \\
\mathrm{cm}(\text { date })^{\ddagger}\end{array}$ & MAST $^{\S}$ & Soil classification* \\
\hline Wright Valley & $\begin{array}{l}77^{\circ} 31.098^{\prime} \mathrm{S} \\
161^{\circ} 51.924^{\prime} \mathrm{E}\end{array}$ & 152 & 46 & $>130(9$ Jan 99$)$ & -19.7 & $\begin{array}{l}\text { Coarse-loamy, mixed, superactive, calcareous, hypergelic } \\
\text { Nitric Anhyorthels }\end{array}$ \\
\hline Victoria Valley & $\begin{array}{l}77^{\circ} 19.854 ' \mathrm{~S} \\
161^{\circ} 36.036^{\prime} \mathrm{E}\end{array}$ & 412 & 21 & 40 (10 Jan 02) & -22.7 & Sandy, mixed, hypergelic Typic Haplorthels \\
\hline Scott Base & $\begin{array}{l}77^{\circ} 50.892^{\prime} \mathrm{S} \\
166^{\circ} 45.642^{\prime} \mathrm{E}\end{array}$ & 38 & 32 & 30 (5 Jan 99) & -18.0 & Sandy-skeletal, mixed, hypergelic Typic Haplorthels \\
\hline Minna Bluff & $\begin{array}{l}78^{\circ} 30.696^{\prime} \mathrm{S} \\
166^{\circ} 45.972^{\prime} \mathrm{E}\end{array}$ & 22 & 22 & 34 (8 Jan 03) & -17.8 & $\begin{array}{l}\text { Loamy-skeletal, mixed, superactive, calcareous, } \\
\text { hypergelic Typic Haploturbels }\end{array}$ \\
\hline Granite Harbour & $\begin{array}{l}77^{\circ} 00.396^{\prime} \mathrm{S} \\
162^{\circ} 31.542^{\prime} \mathrm{E}\end{array}$ & 5 & $>90$ & 80 (11 Jan 03) & -14.6 & Sandy-skeletal, mixed, hypergelic Typic Haplorthels \\
\hline
\end{tabular}

† From Adlam et al. (2010).

¥ Date ice-cemented ground was observed.

$\S$ MAST $=$ Mean Annual Soil Temperature.

* Soil Survey Staff (2006). 
of the $<2 \mathrm{~mm}$ fraction of soil. Properties determined on the $<2 \mathrm{~mm}$ soil fraction were percent sand, silt, and clay (pipette method), water content at $-1500 \mathrm{kPa}$ tension (pressure-membrane extraction using sieved samples), and electrical conductivity (saturated paste). Data are reported on an oven-dry basis. All of the above methods are described in Burt (2004). Maximum active layer depths for the seven sites are reported in Adlam et al. (2010).

Soil water content was measured with the hydra-probe sensor (Stevens Water Monitoring Systems, Portland, Oregon). The hydro-probe sends a $50 \mathrm{MHz}$ electromagnetic signal into the soil and the reflected wave is associated with the dielectric permittivity of the soil, which is then related to the soil water content and conductivity. Output from the hydra-probe consists of four voltages that are converted using software provided by the manufacturer. The fourth voltage is soil temperature measured by a calibrated thermistor embedded in the sensor head. One of four calibration curves, provided by the manufacturer, was selected to convert voltages to volumetric water content depending on the texture of the soil (i.e. sand, silt, clay and loam). The sand calibration curve was used in this study. The probes temperature range is from $-10^{\circ} \mathrm{C}$ to $+65^{\circ} \mathrm{C}$, and can only measure water in the liquid state. Liquid water in the soil can exist with ice at temperatures well below the normal freezing point of water $\left(0^{\circ} \mathrm{C}\right)$, but the hydra-probe cannot detect water in the form of ice. Therefore, only water content values corresponding to soil temperatures $>0^{\circ} \mathrm{C}$ were used in this study to assure that only liquid water is present. If liquid water and ice exist, an underestimate of the water content will result. According to the manufacturer, the accuracy of the hydra-probe, knowing the general soil type (i.e. sandy), is less than $+/-0.02 \mathrm{~m}^{3} \mathrm{~m}^{-3}$, and the precision is typically $+/-0.003 \mathrm{~m}^{3} \mathrm{~m}^{-3}$ (Stevens Vitel 1994). Seyfried et al. (2005) and Kelleners et al. (2009) have shown that the hydra-probe can provide reliable and accurate measurements of soil water content under a variety of soil types and surface conditions, and that a sensor-specific calibration is not necessary for most applications. For saline soils, the hydraprobe will still provide accurate dielectric permittivity measurements up to $1.5 \mathrm{~S} \mathrm{~m}^{-1}$ (Stevens 2007). Hydra-probe sensors were placed in duplicate at the 2, 20,30,50 and $120 \mathrm{~cm}$ depths at Wright Valley; at the 3,10 and $33 \mathrm{~cm}$ depths at Victoria Valley; in triplicate at the 2, 20, 50 and $80 \mathrm{~cm}$ depths at Marble Point; in triplicate at the 2, 15, 25 and $40 \mathrm{~cm}$ depths at Scott Base; in duplicate at the 10, 15, 20 and $37 \mathrm{~cm}$ depths at Minna Bluff; at the 2, 5, 15, 25, 45 and $75 \mathrm{~cm}$ depths at Granite Harbour; and in duplicate at the 7, 15 and $30 \mathrm{~cm}$ depths at Mount Fleming.

Soil temperature was measured with both multiple thermistor probes (Measurement Research Corporation, Gig Harbor, Washington) and single thermistor temperature sensors (model 107; Campbell Scientific, Logan, Utah), except at Mount Fleming where only single thermistor sensors were used. Incoming solar radiation was measured
Table II. Soil particle and fine gravel $(2-5 \mathrm{~mm})$ distribution at the seven soil climate stations.

\begin{tabular}{|c|c|c|c|c|c|}
\hline Site & $\begin{array}{l}\text { Depth } \\
(\mathrm{cm})\end{array}$ & Clay & $\begin{array}{c}\text { Silt } \\
\text { wt } \% \text { of }<5 \mathrm{~mm}\end{array}$ & $\begin{array}{l}\text { Sand } \\
\text { fraction }\end{array}$ & $2-5 \mathrm{~mm}$ \\
\hline \multirow[t]{9}{*}{ Wright Valley } & $0-3$ & 1.2 & 2.8 & 80.0 & 16.0 \\
\hline & $3-12$ & 4.7 & 11.0 & 74.4 & 9.9 \\
\hline & $12-18$ & 5.9 & 34.1 & 56.6 & 3.4 \\
\hline & $18-28$ & 5.4 & 31.8 & 59.3 & 3.5 \\
\hline & $28-38$ & 5.5 & 29.0 & 61.0 & 4.5 \\
\hline & $38-51$ & 4.1 & 28.6 & 60.5 & 6.8 \\
\hline & $51-78$ & 4.6 & 32.0 & 57.7 & 5.7 \\
\hline & $78-109$ & 3.3 & 23.6 & 62.6 & 10.5 \\
\hline & 109-130 & 4.3 & 30.4 & 53.3 & 12.0 \\
\hline \multirow[t]{3}{*}{ Victoria Valley } & $0-2$ & 0.8 & 2.0 & 86.9 & 10.2 \\
\hline & $2-8$ & 3.2 & 5.1 & 79.4 & 12.3 \\
\hline & $8-40$ & 0.6 & 0.6 & 96.6 & 2.2 \\
\hline \multirow[t]{6}{*}{ Marble Point } & $0-3$ & 1.5 & 6.6 & 74.9 & 17.1 \\
\hline & $3-15$ & 0.8 & 10.0 & 76.7 & 12.5 \\
\hline & $15-32$ & 1.2 & 12.6 & 72.2 & 14.0 \\
\hline & $32-45$ & 2.0 & 11.4 & 63.7 & 22.9 \\
\hline & $45-69$ & 2.7 & 12.4 & 55.1 & 29.7 \\
\hline & 69-100 & 6.1 & 19.3 & 58.2 & 16.4 \\
\hline \multirow[t]{5}{*}{ Scott Base } & $0-1$ & 5.0 & 8.6 & 60.8 & 25.6 \\
\hline & $1-7$ & 6.1 & 11.1 & 82.7 & - \\
\hline & $7-15$ & 3.3 & 5.4 & 56.1 & 35.2 \\
\hline & $15-30$ & 2.9 & 6.0 & 53.1 & 38.1 \\
\hline & $30-45$ & 2.3 & 18.7 & 52.6 & 26.4 \\
\hline \multirow[t]{5}{*}{ Minna Bluff } & $0-4$ & 1.8 & 10.6 & 47.4 & 40.2 \\
\hline & $4-10$ & 21.1 & 20.4 & 34.0 & 24.5 \\
\hline & $10-30$ & 19.8 & 16.9 & 25.6 & 37.8 \\
\hline & $30-60$ & - & - & - & - \\
\hline & $60-80$ & 26.6 & 21.8 & 22.6 & 28.9 \\
\hline \multirow[t]{5}{*}{ Granite Harbour } & $0-2$ & 1.2 & 1.6 & 73.2 & 24.0 \\
\hline & $2-10$ & 2.3 & 1.9 & 77.1 & 18.8 \\
\hline & $10-30$ & 0.5 & 1.6 & 72.1 & 25.9 \\
\hline & $30-70$ & 0.5 & 12.0 & 84.2 & 3.3 \\
\hline & $70-80$ & - & - & - & - \\
\hline \multirow[t]{5}{*}{ Mount Fleming } & $0-2$ & 4.9 & 6.7 & 70.7 & 17.8 \\
\hline & $2-8$ & 14.2 & 8.2 & 68.0 & 9.6 \\
\hline & $8-20$ & 15.4 & 12.0 & 67.3 & 5.3 \\
\hline & $20-45$ & 8.6 & 11.4 & 73.7 & 6.3 \\
\hline & $45-70$ & 6.8 & 17.4 & 65.3 & 10.5 \\
\hline
\end{tabular}

with a pyranometer (model LI200X; Campbell Scientific). Wind speed and direction were measured with a Met One (model 0343; Campbell Scientific) or R.M. Young (model 05103; Campbell Scientific) sensor. Relative humidity was measured with a Vaisala capacitive relative humidity sensor (model HMP45C or HMP35C; Campbell Scientific), which also measured air temperature with a platinum resistance temperature detector, mounted in a gill radiation shield. At most stations, air temperature was also measured with a single thermistor probe (model 107; Campbell Scientific) mounted inside a gill radiation shield. At the Wright Valley SCS, air temperature was measured with a R.M. Young RTD Probe (model 43347; Campbell Scientific) mounted inside a gill radiation shield. The wind and solar radiation sensors 
Table III. Mean water contents and range in water contents, and hours above freezing in the active layer for each depth at the seven climate stations.

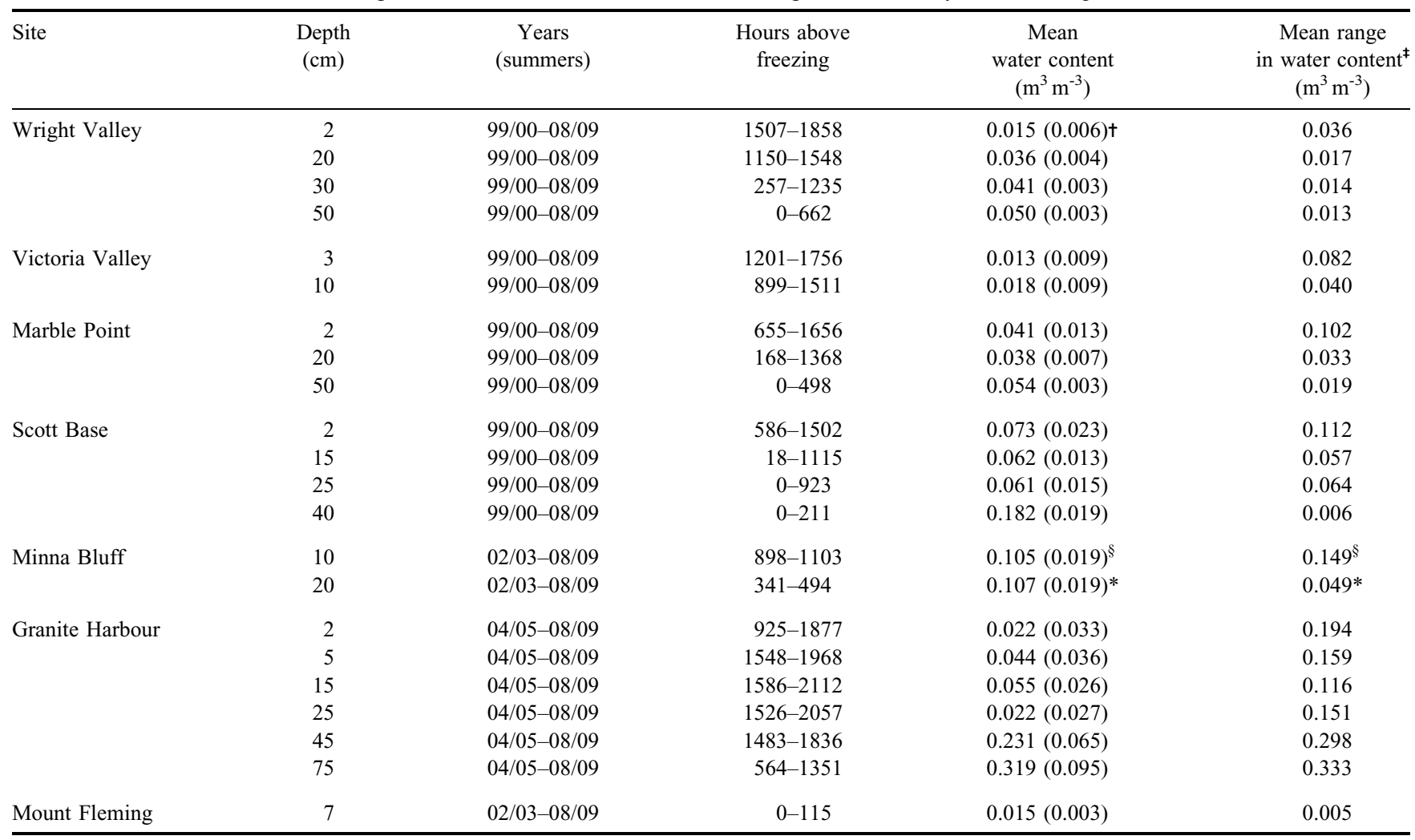

† Number in parentheses is the standard deviation.

¥ The mean difference between the season minimum and maximum water content values.

$\S$ Summer season 08/09.

* Summer seasons 04/05 and 05/06.

were mounted three metres above the ground. The relative humidity/air temperature sensor was mounted $1.6 \mathrm{~m}$ above the ground, and the air temperature sensor was mounted $2 \mathrm{~m}$ above the ground.

All sensors were connected to a data logger with a wiring panel (CR10X-2M; Campbell Scientific, Logan, Utah) and a 16-channel 4-wire input relay multiplexer (Campbell Scientific) that were enclosed in a water tight $40 \times 45 \times 23 \mathrm{~cm}$ fibreglassreinforced polyester enclosure (model ENC16/18; Campbell Scientific). Power was supplied by three $12 \mathrm{~V}, 24 \mathrm{Ahr}$ sealed rechargeable batteries (BP24; Campbell Scientific) either enclosed with the data logger or enclosed in separate containers on the ground. Batteries were powered by a 20 Watt solar panel and regulated through a $12 \mathrm{~V}$ charging regulator (model CH100 or CH12R; Campbell Scientific). The enclosure was mounted on a 10 foot galvanized steel tripod with a mast and cross arm (model CM10; Campbell Scientific).

Measurements of atmospheric variables were made at 10 second intervals, and soil measurements were made at 20 minute intervals. All measurements were averaged every hour and the hourly averages recorded in the datalogger and storage module (Campbell Scientific, Logan, Utah). Data was collected from the climate stations annually.
Mean daily and seasonal water contents, as well as mean liquid water contents for the entire monitoring period, were calculated. The water contents reported were not corrected for coarse fragments and represent the volume of water in the $<5 \mathrm{~mm}$ fraction of the soil - that which can fit between the tines of the sensor. The hydra-probe effective sensing volume is a cylinder c. $2.5 \mathrm{~cm}$ in diameter and $6 \mathrm{~cm}$ in length bounded by the three outer tines, the probe head, and the free end of the tines. The resulting probe output parameters reflect an average value over this sensing volume.

\section{Results and discussion}

All the soils are classified as Gelisols according to Soil Taxonomy (Soil Survey Staff 2006) because they have permafrost within one metre of the soil surface (Table I). In Antarctica, permafrost does not necessarily correspond to the depth of ice-cemented ground because dry permafrost can exist (due to insufficient moisture in the soil to form ice-cement). The difference between the observed depth to ice-cement and the maximum active layer depth is the dry permafrost. Only at the Granite Harbour and Scott Base SCSs does the depth to ice-cemented ground correspond to permafrost. The depth to ice-cemented ground is used in 
Table IV. Selected soil properties from the pedons at the seven soil climate stations.

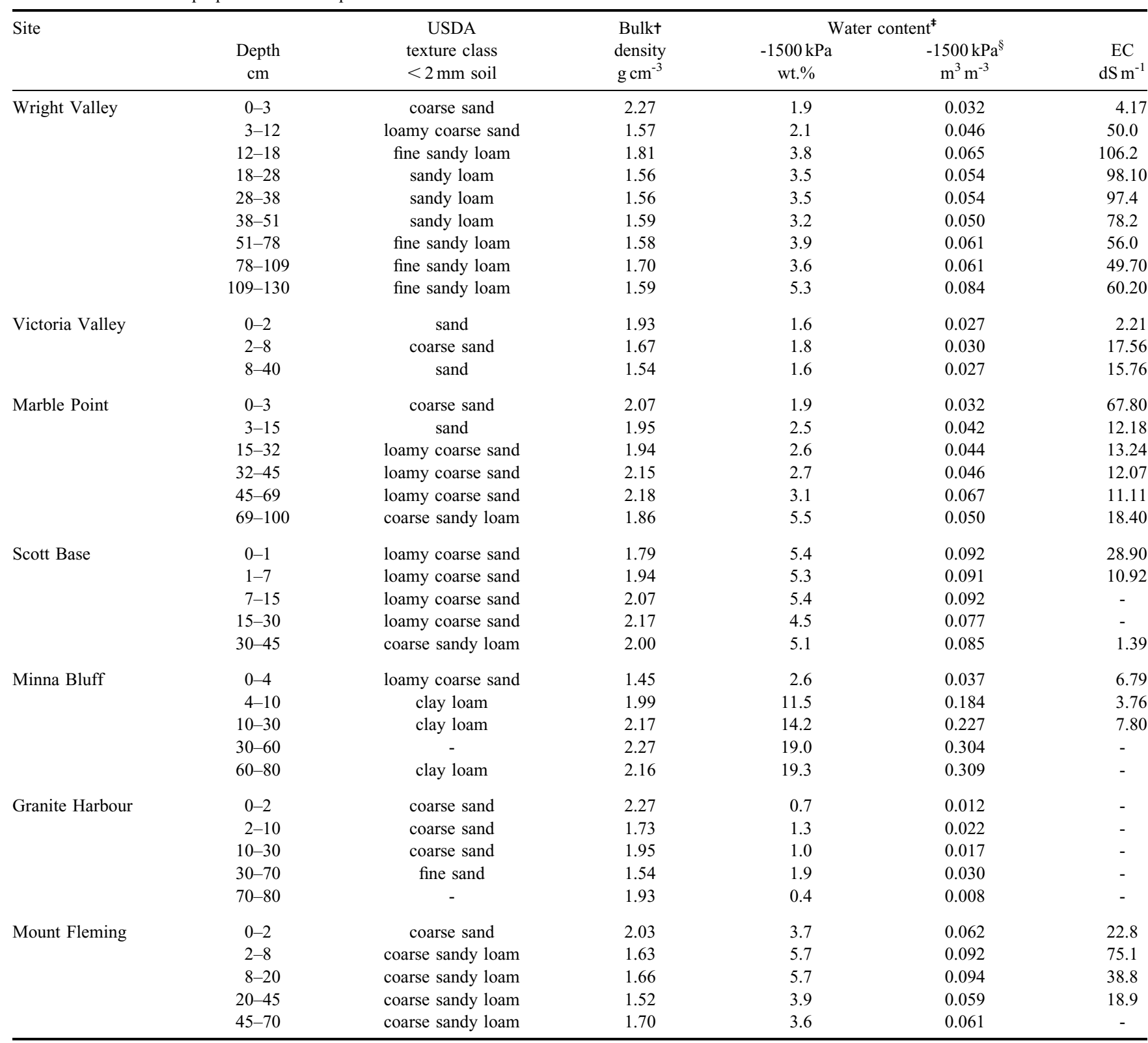

t Bulk density of the $<75 \mathrm{~mm}$ fraction of soil.

$\ddagger$ Determined on the $<2 \mathrm{~mm}$ soil fraction.

$\S$ Estimated by multiplying by a bulk density estimate of the $<2 \mathrm{~mm}$ soil fraction.

classifying soils. The soil at the Wright Valley SCS has a depth to ice-cemented ground that is $>70 \mathrm{~cm}$, which puts the soil in the taxonomic great group Anhyorthels, which are further classified based on the type and presence of salts. There was an accumulation of nitrates in the profile at the Wright Valley site, which classifies as a Nitric Anhyorthels (Table I). Source of the nitrates could be from snowfall (Witherow et al. 2006) and has been attributed to a combination of tropospheric transport of photochemically produced $\mathrm{HNO}_{3}$ and $\mathrm{HNO}_{3}$ formed in the stratosphere (Michalski et al. 2005). There is strong evidence that the freezing process transports ions downward in the soil (Lundin
\& Johnsson 1994). The Minna Bluff site has evidence of cryoturbation and was classified as a Haploturbel. The rest of the soils are noncryoturbated and default to Haplorthels. In the present study, all soils had a mean annual soil temperature (at a depth of $50 \mathrm{~cm}$ ) that was lower than $-10^{\circ} \mathrm{C}$, which puts them in the hypergelic soil temperature class (Table I). Mount Fleming and the four coastal sites have soils that are dominated by rock fragments ( $>2 \mathrm{~mm}$ in size), but have at least $10 \%$ fine earth material by volume, which puts them in the skeletal taxonomic family particle-size class (see Appendix A for rock fragment contents). Rock fragments $(>2 \mathrm{~mm})$ influence soil hydraulic properties by affecting soil 
porosity and the tortuosity of water flow paths (Sauer \& Logsdon 2002).

The size of the soil particles determines the amount of pore space and volume of water than can be held in the soil. In general, sand dominates the $<5 \mathrm{~mm}$ fraction of soil at all sites except at Minna Bluff, where the sand and 2-5 $\mathrm{mm}$ fractions dominate (Table II). Because of the coarse textures, all soils in this study have low water holding capacities. Furthermore, the soils contain numerous rock fragments $>5 \mathrm{~mm}$ in size (Appendix A) that take up space in the soil, reducing the total porosity, which further reduces the total water holding capacity of the whole soil. Water contents presented in this study are those of the $<5 \mathrm{~mm}$ fraction of soil. Water contents on whole soil basis would require subtracting out the total volume of fragments that are $>5 \mathrm{~mm}$ (Bower \& Rice 1984).

The Mount Fleming and Minna Bluff sites have the highest clay contents, between 14 and $27 \%$ of the $<5 \mathrm{~mm}$ fraction, with Minna Bluff having the greatest amount. The Wright Valley site contains the greatest amount of silt, ranging up to $35 \%$ of the $<5 \mathrm{~mm}$ fraction.

\section{Active layer liquid water contents}

Measurable volumes of liquid water only occur when soils are near to or above $0^{\circ} \mathrm{C}$. The depth and duration of soil thaw (Tables I \& III) show that temperatures $>0^{\circ} \mathrm{C}$ are limited to brief summer periods. The depth of thaw was greatest at Granite Harbour and smallest at Mount Fleming (Table I). The duration of thaw varied markedly between sites and seasons ranging from no thawing in some years at Mount Fleming to over 2000 hours (or about 12 weeks) in some summers at Granite Harbour (Table III).

Volumetric water contents (measured when temperatures were $>0^{\circ} \mathrm{C}$ ) at each depth were averaged (across replicates and summer seasons) for the entire monitoring period and are presented in Table III. Mean water contents ranged from $0.013 \mathrm{~m}^{3} \mathrm{~m}^{-3}$ near the surface at Victoria Valley to $0.33 \mathrm{~m}^{3} \mathrm{~m}^{-3}$ near the ice-cemented layer, in soil, along the coast at Granite Harbour. The near-surface soils at the Dry Valley sites and at Mount Fleming were the driest, ranging from $0.013-0.015 \mathrm{~m}^{3} \mathrm{~m}^{-3}$ water contents. The coastal sites (i.e. Granite Harbour, Scott Base, Marble Point and Minna Bluff) have greater water contents, which is expected and has been shown by others (Cameron \& Conrow 1969, Barrett et al. 2006). Marble Point is the driest of the coastal sites, and has similar subsurface water contents, but greater near-surface water contents compared to the inland sites. At all sites where there was more than one depth of recorded moisture, water contents generally increased with depth in the active layer (Table III). The largest water contents were found near the ice-cemented permafrost. Water contents at Minna Bluff were consistently higher, on average, throughout the active layer than at the other sites $\left(0.105-0.107 \mathrm{~m}^{3} \mathrm{~m}^{-3}\right)$. This could be due to the higher water holding capacity of the fine earth fraction (i.e. clay loam texture), which will have a

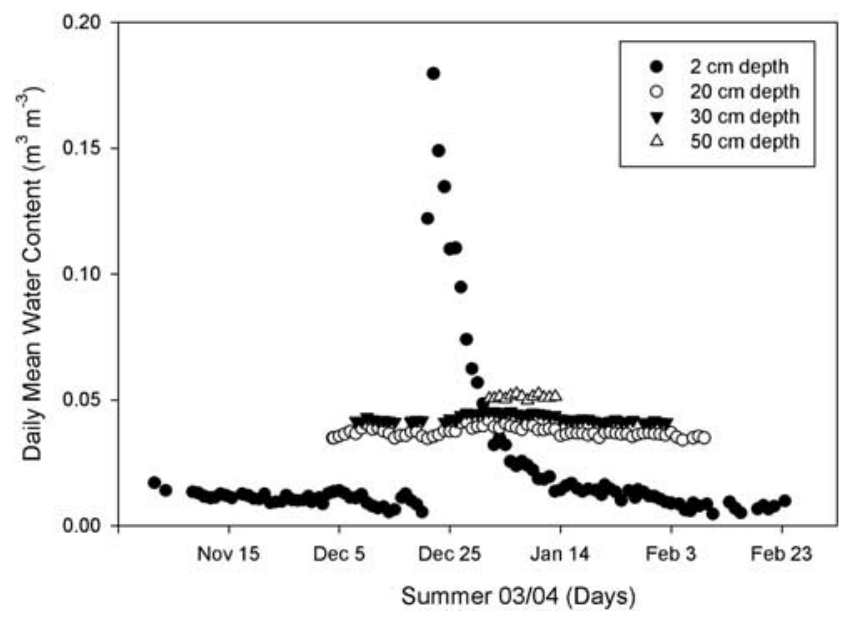

Fig. 2. Daily mean soil liquid water contents in the active layer for the Wright Valley soil climate station in summer 2003-04.

greater water holding capacity than the sandier textures. The retention of water at $-1500 \mathrm{kPa}$ is about three times higher at Minna Bluff (12-14\% by weight) than that in the other soils ( $0.4-5 \%$ by weight), indicating a much higher water holding capacity at low tensions (Table IV).

The range in water content at each depth, averaged across summer seasons, was generally greater near the surface and decreased with depth (Table III). The greater range in water contents near the surface was due to occasional surface wetting events during the monitoring period. Precipitation occurs primarily as snow and can occur at any time of the year (Fountain et al. 2009). Coastal sites tend to have more snowfall than inland sites. In the Dry Valleys, wind-drift snow is an important contribution to the total snow accumulation, which contributes about half the snow amounts (Fountain et al. 2009). Any accumulated snow either sublimates, or melts and then infiltrates the soil (i.e. wetting event) or evaporates.

For mineral soils, the thermal diffusivity increases with water content at low water contents $\left(<0.15 \mathrm{~m}^{3} \mathrm{~m}^{-3}\right.$ for sandy

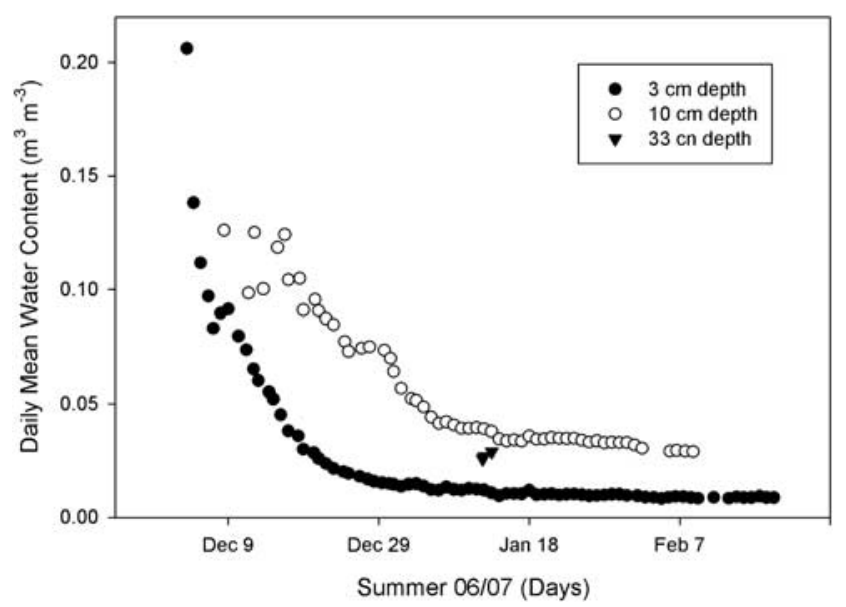

Fig. 3. Daily mean soil liquid water contents in the active layer for the Victoria Valley soil climate station in summer 2006-07. 


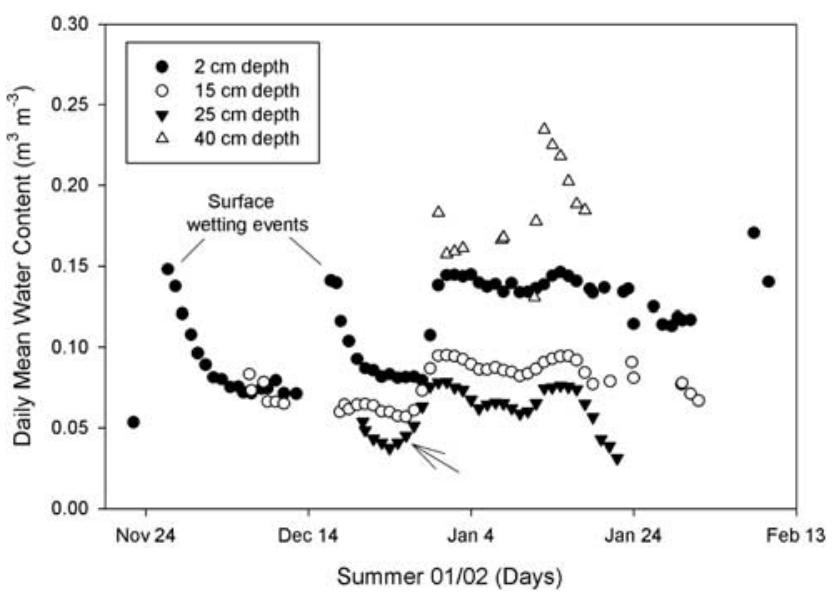

Fig. 4. Daily mean soil liquid water contents in the active layer for the Scott Base soil climate station in summer 2001-02. The arrow points to wetting from upslope subsurface water flow.

soils) and then gradually decreases with increasing water contents at higher water contents (Jury et al. 1991). The thermal diffusivity generally characterizes the rate at which a heat pulse will diffuse through the soil. Soils with high thermal diffusivity will rapidly adjust their temperature to that of their surroundings. Water contents of the soils in this study are generally much less than $0.15 \mathrm{~m}^{3} \mathrm{~m}^{-3}$, therefore small increases in water contents would increase the thermal diffusivity for short periods until the soil dried. The more wetting events and deeper penetration of the wetting events, the greater the potential to increase the thaw depth or its duration at a site.

\section{Wright Valley}

At the Wright Valley site, there were only two obvious wetting events over the entire ten year monitoring period where the water content increased from 0.02 to $0.05 \mathrm{~m}^{3} \mathrm{~m}^{-3}$ in the summer of 1999-2000 and from 0.02 to $0.20 \mathrm{~m}^{3} \mathrm{~m}^{-3}$ in the summer of 2003-04 (Fig. 2). The later wetting event took about 14 days to dry to the summer minimum water content, which can be considered air-dry. There are a few instances where the water content at the beginning of the thaw period, started out about $2 \%$ higher and then would dry to the season minimum. There was no detectable increase or decrease in water content at the $20 \mathrm{~cm}$ depth as a result of any wetting event, which indicates that liquid water from snowmelt did not reach the $20 \mathrm{~cm}$ depth at the Wright Valley site. The amount of water that infiltrated between the two replicates at this site did vary. Snow may accumulate on the leeward side of boulders and stones that can survive as snowmelt, creating variable amounts of infiltrated water. Sparse snow patches in the Dry Valleys are an important source of soil moisture (Gooseff et al. 2003). Isolated patches, up to $5 \mathrm{~m}$ in diameter, of moist surface soil were observed in the area of the Wright Valley Climate station a day or so after a snowfall event in January 2010. However, much of the snowfall sublimated
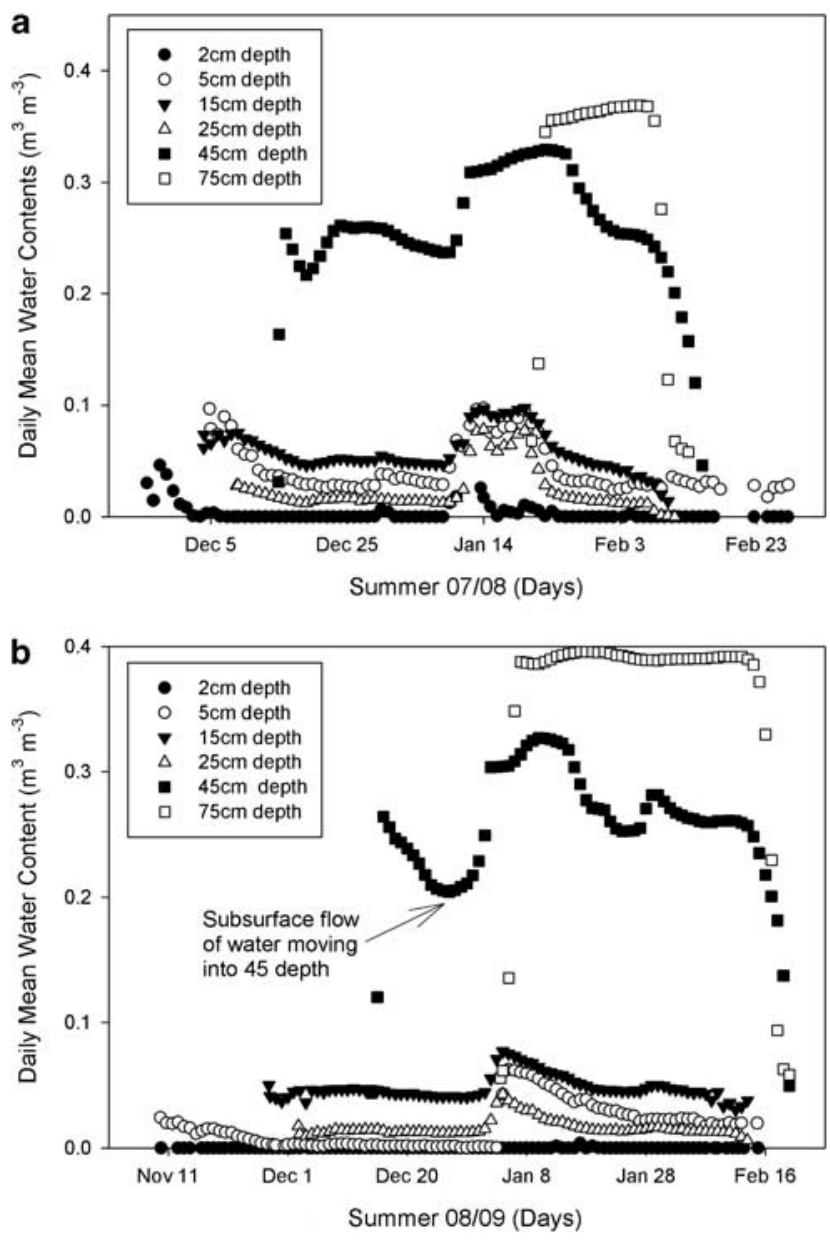

Fig. 5. Daily mean soil liquid water contents in the active layer for the Granite Harbour soil climate station. a. summer 2007-08, b. summer 2008-09.

within a few hours of falling with no visible soil moistening. The event was not detected by our sensors.

\section{Victoria Valley}

At the Victoria Valley SCS, there were one to three wetting events that occurred each summer over the course of the ten year monitoring period. Increases in water content ranged from 0.02 to $0.18 \mathrm{~m}^{3} \mathrm{~m}^{-3}$ (at the $3 \mathrm{~cm}$ depth) and up to $0.12 \mathrm{~m}^{3} \mathrm{~m}^{-3}$ at the $10 \mathrm{~cm}$ depth. At the beginning of the thaw period in 2002-03 and 2006-07, water contents started out at their maximum of 0.08 and $0.18 \mathrm{~m}^{3} \mathrm{~m}^{-3}$, respectively, at the $3 \mathrm{~cm}$ depth (Fig. 3). Snowmelt can infiltrate frozen soil (Spaans \& Baker 1996) which can result in maximum water contents at the beginning of the thaw period. Also, since water can exist below freezing, it is possible that water existed slightly below $0^{\circ} \mathrm{C}$ when snowmelt infiltrated. Water did percolate to the $10 \mathrm{~cm}$ depth in both events. In the few hours when the $33 \mathrm{~cm}$ depth contained liquid water, the water content was generally greater than that at the $10 \mathrm{~cm}$ depth (data not shown). After each wetting event the soil would begin to dry out (become 

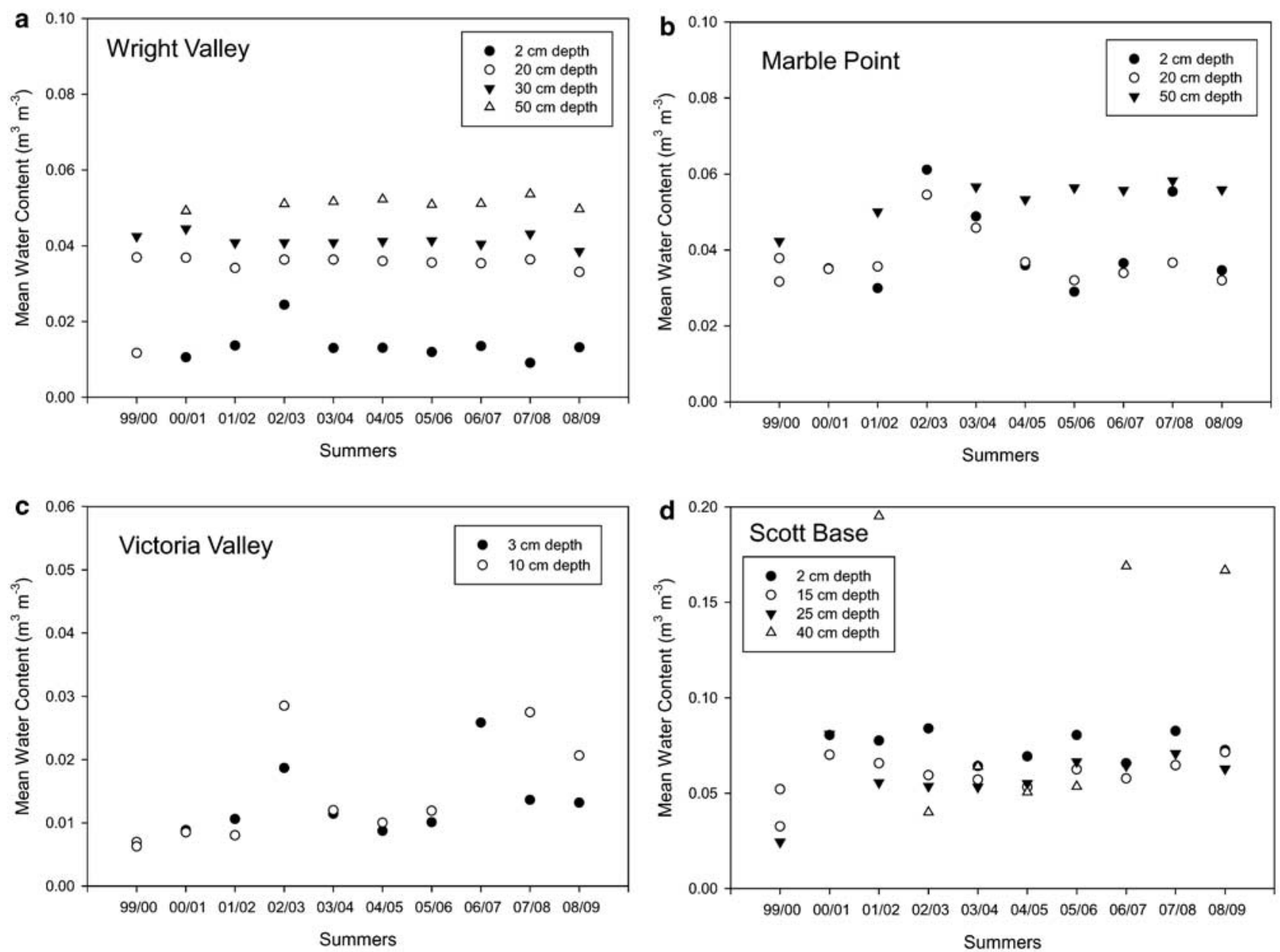

Fig. 6. Trends in the mean soil liquid water contents of the active layer. a. Wright Valley soil climate station, b. Marble Point soil climate station, c. Victoria Valley soil climate station, d. Scott Base soil climate station.

air-dry); taking up to 16 days to dry after reaching its maximum moisture content (at the $3 \mathrm{~cm}$ depth). Hagedorn et al. (2010) have shown (through the signature of water) that snowmelt is sufficient to compensate modelled sublimation rates, and therefore conserve ground ice at this Victoria Valley site.

\section{Marble Point}

At the Marble Point site there were generally one to four wetting events per summer over the ten year monitoring period. At the $2 \mathrm{~cm}$ depth, the maximum water content ranged from $0.05-0.21 \mathrm{~m}^{3} \mathrm{~m}^{-3}$ as a result of any given wetting event. Some wetting events occurred at the beginning of the thaw period, which generally produced the largest water contents. There were several small increases in water contents $\left(<0.05 \mathrm{~m}^{3} \mathrm{~m}^{-3}\right)$ due to a wetting event. After each wetting event the soil would begin to dry. The water content at the $20 \mathrm{~cm}$ depth did increase in the summer of 2002-03 at all three replicates and in the summer of 2007-08 at the beginning of the thaw period where there was a large increase in water $\left(\approx 0.1 \mathrm{~m}^{3} \mathrm{~m}^{-3}\right)$ at the $2 \mathrm{~cm}$ depth. However, in most years, the water content did not increase at the $20 \mathrm{~cm}$ depth as a result of a wetting event. When the $50 \mathrm{~cm}$ depth thawed, the water content was generally at its highest level and then would decrease (dry) slightly over the thawed period. In addition to vertical movement of snow meltwater, water may be moving laterally within the active layer as there are nearby surface waters.

\section{Scott Base}

At the Scott Base site, there was generally one to about four wetting events per summer season at the $2 \mathrm{~cm}$ depth over the 10 year monitoring period. Increases in water contents from a wetting event ranged from 0.02 up to $0.16 \mathrm{~m}^{3} \mathrm{~m}^{-3}$ at the $2 \mathrm{~cm}$ depth. Liquid water did percolate downward to the 15 and $25 \mathrm{~cm}$ depths in some instances. Also, subsurface movement of water from upslope has been observed to occur, increasing water contents of the active layer, especially at the 25 and $40 \mathrm{~cm}$ depths above the ice-cemented permafrost. The $40 \mathrm{~cm}$ depth did not thaw in most years. In Fig. 4, water contents increased at the $25 \mathrm{~cm}$ depth first (see arrow in graph), then at the $15 \mathrm{~cm}$ depth, and then at the $2 \mathrm{~cm}$ depth, indicating 
that water was coming from the subsurface and moving upward in the active layer. The 2001-02 summer (shown in Fig. 4) was the warmest summer in our record, with the deepest active layer depths recorded at a number of sites (Adlam et al. 2010), and considerable meltwater reported in the Dry Valleys. Melting to a deeper than usual permafrost interface may have contributed to the moisture observed. The Scott Base SCS is on a back slope, where water can move laterally down hill above the permafrost from snow and permafrost melt which may also have contributed to the raised moisture status recorded.

\section{Minna Bluff}

At the Minna Bluff site, there were several years of incomplete moisture data and some years of no data for a summer due to sensor failure. With the limited data, up to three wetting events occurred at Minna Bluff each summer. The 2008-09 summer season had a complete set of moisture data at the $10 \mathrm{~cm}$ depth, which showed early wetting from snowmelt at the beginning of the thaw period $\left(0.20 \mathrm{~m}^{3} \mathrm{~m}^{-3}\right)$, and then a gradual drying with one small wetting event, never dropping below $0.08 \mathrm{~m}^{3} \mathrm{~m}^{-3}$. At Minna Bluff, water contents tend to start out at their maximum and decrease over the summer season (dry to the season minimum).

\section{Granite Harbour}

One to three wetting events occurred during each summer season at the Granite Harbour site, with a maximum surface wetting of up to about $0.08 \mathrm{~m}^{3} \mathrm{~m}^{-3}$ at the $2 \mathrm{~cm}$ depth. Water contents at lower depths did increase as a result of surface wetting events (Fig. 5a). Subsurface wetting events also occurred from lateral subsurface flow of meltwater from upslope along the ice-cemented permafrost. An example of a subsurface wetting event is shown in Fig. $5 \mathrm{~b}$. The $45 \mathrm{~cm}$ depth is increasing in water content, first, from upslope subsurface flow. Through unsaturated subsurface flow, the shallower depths showed increasing water contents, but the increase did not reach the near-surface $(2 \mathrm{~cm})$ depth. The shallow depths reached their maximum water content a few hours after the $45 \mathrm{~cm}$ depth reached its maximum. As the $75 \mathrm{~cm}$ depth thawed, more lateral flow of water moved into the $45 \mathrm{~cm}$ depth. This subsurface flow was also observed and could be heard at the site. Water contents at the 45 and $75 \mathrm{~cm}$ depths generally start out high and get wetter from upslope subsurface flow and then decrease towards the end of the thaw season (Fig. 5). The rapid increase or decrease (e.g. from 0.38 to $0.05 \mathrm{~m}^{3} \mathrm{~m}^{-3}$ ) in water content at the 45 and $75 \mathrm{~cm}$ depths is due to water thawing or freezing. The drop in liquid water content during freezing is analogous to soil drying.

\section{Mount Fleming}

There were no wetting events at the Mount Fleming site during the thaw period, which was very short - only a few

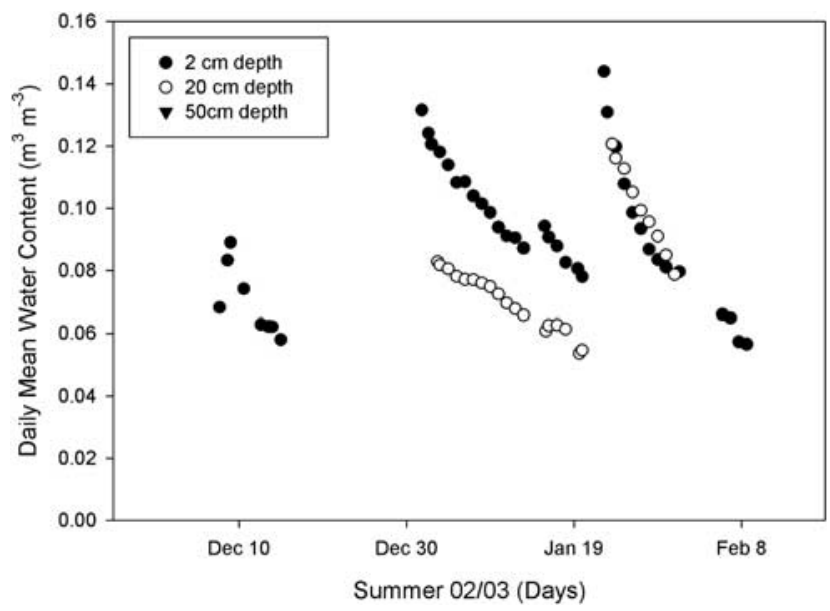

Fig. 7. Daily mean soil liquid water contents in the active layer for the Marble Point soil climate station in summer 2002-03 showing four wetting events and higher than average infiltration of meltwater.

hours in some years (Table III). The air temperature at the Mount Fleming site was never above freezing during the study period, and is frequently subject to blowing snow. Frost/ ice crystals have been observed in the upper $15 \mathrm{~cm}$ of the soil.

\section{Active layer liquid water content trends}

The year-to-year active layer mean water contents remained consistent over the monitoring period (Fig. 6a-d). There was some year-to-year variability, but no significant decreasing or increasing trend in active layer soil water contents over the monitoring period. The temporal variability of water content at the Wright Valley site was the lowest, varying within $0.01 \mathrm{~m}^{3} \mathrm{~m}^{-3}$ (Fig. 6a). The 2002-03 summer was consistently wetter across the Wright Valley, Victoria Valley, and Marble Point sites (Fig. 6a-c). The greater water contents are due to greater infiltration of snow meltwater during the 2002-03 summer (e.g. Fig. 7). The previous summer (2001-02) was warmer than average, leading to higher than usual Onyx River flows (Doran et al. 2008). However, our sites did not show an increase in soil moisture during that warm summer. The increased flow in the rivers was attributed primarily to increased glacier meltwater.

The water contents were averaged over the entire monitoring period for each site and were strongly correlated to the mean annual air temperature $(r=0.76)$ and the air relative humidity $(r=0.68)$. In general, as the air temperature and relative humidity increased, so did the soil moisture content. Latitude was weakly correlated to the mean active layer water contents $(r=0.30)$. The coastal sites alone (which lie along a latitudinal gradient) resulted in no correlation with active layer water contents. It is evident that the local microclimate and topography have a greater influence on active layer water contents than the latitudinal gradient of these sites. It has been shown that local microclimates are more important than 
regional and environmental gradients in influencing soil development (Cannone et al. 2008) and explaining variation in soil biodiversity and ecosystem functioning (Barrett et al. 2006). Using all sites, the mean water content was negatively correlated to the elevation $(r=-0.62)$. As the elevation increases the moisture content tended to decrease. The inland sites were drier and at a higher elevation than the coastal sites, explaining the negative correlation with elevation. Bockheim (2008) also reports a general decrease in soil moisture from the coast inland in the Ross Sea Region.

\section{Conclusions}

Mean water contents in the active layer range from $0.013-0.015 \mathrm{~m}^{3} \mathrm{~m}^{-3}$ in the surface soils of the Dry Valley sites, to $0.182-0.319 \mathrm{~m}^{3} \mathrm{~m}^{-3}$ near the ice-cemented layer at two of the coastal sites. The coastal sites have greater soil water contents than the Dry Valley sites, and the water contents generally increase with depth in the active layer. The Wright Valley site receives very little infiltration from snowmelt, with none in most years. Any water that infiltrates does not reach the $20 \mathrm{~cm}$ depth. The Victoria Valley site receives one to three wetting events per summer in which infiltrated water does move to lower depths in some cases. The Marble Point site receives one to four wetting events per summer and infiltrated water does move to the $20 \mathrm{~cm}$ depth in some cases. The Scott Base site receives about one to four and Granite Harbour receives about one to three wetting events per summer. At both the Scott Base and Granite Harbour sites, water does move to greater depths. Also, the Scott Base and Granite Harbour sites are situated on sloping ground and receive subsurface flow of water from upslope along the ice-cemented permafrost, which does provide for subsurface wetting events. Up to three wetting events occurred each summer at the Minna Bluff SCS (with only one complete summer of data). There was no wetting events recorded at the cold and windy Mount Fleming site, though it is frequently subject to blowing snow. There was no significant decreasing or increasing trend in active layer soil water contents over the ten year monitoring period (1999-2009) at the Scott Base, Victoria Valley, Wright Valley, and Marble Point sites. Soil water contents were positively correlated with air temperature, and relative humidity, all pointing to coastal sites having greater water contents. In general, water contents are low, there is very little recharge and water contents are consistent between summers. The local microclimate and topography have a greater influence on active layer water contents than the latitudinal gradient of the study area.

\section{Acknowledgements}

This research was partially funded by The New Zealand Foundation for Research Science and Technology (FRSTgrant CO930307). Logistics support for this project was provided by Antarctica New Zealand. We acknowledge the contribution of John Kimble (retired from USDA-NRCS), Ron Paetzold (retired from USDA-NRCS), Don Huffman (retired from USDA-NRCS), and Iain Campbell (Land and Soil Consultancy Services) who all assisted in the initial installation of the climate stations and with maintenance in the following years. The Victoria Valley soil climate station was installed by Ron Sletten (University of Washington) who is a collaborator on this site.

\section{References}

Adlam, L.S., Balks, M.R., Seybold, C.A. \& Campbell, D.I. 2010. Temporal and spatial variation in active layer depth in the McMurdo Sound region, Antarctica. Antarctic Science, 22, 45-52.

Balks, M.R., Paetzold, R.F., Kimble, J.M., Aislabie, J. \& Campbell, I.B. 2002. Effects of hydrocarbon spills on the temperature and moisture regimes of Cryosols in the Ross Sea region. Antarctic Science, 14, 319-326.

Barrett, J.E., Virginia, R.A., Hopkins, D.W., Aislabie, J., Bargagli, R., Bockheim, J.G., Campbell, I.B., Lyons, W.B., Moorhead, D.L., Nkem, J.N., Sletten, R.S., Steltzer, H., Wall, D.H. \& Wallenstien, M.D. 2006. Terrestrial ecosystem processes of Victoria Land, Antarctica. Soil Biology \& Biochemistry, 38, 3019-3034.

Bockheim, J.G. 2008. Functional diversity of soils along environmental gradients in the Ross Sea region, Antarctica. Geoderma, 144, 32-42.

Bower, H. \& Rice, R.C. 1984. Hydraulic properties of stony vadose zones. Ground Water, 22, 696-705.

Burt, R. 2004. Soil survey laboratory methods manual. Soil Survey Investigations Report, No. 42, ver.4.0. Washington, DC: US Government Printing Office, 700 pp. [Available on-line at http:// soils.usda.gov/technical/1mm/]

Cameron, R. \& Conrow, H.P. 1969. Soil moisture, relative humidity, and microbial abundance in Dry Valleys of Southern Victoria Land. Antarctic Journal of the United States, 4(1), 23-28.

Campbell, I.B., Claridge, G.G.C. \& Balks, M.R. 1994. The effect of human activities on moisture content of soils and underlying permafrost from the McMurdo Sound region, Antarctica. Antarctic Science, 6, 307-314.

Campbell, I.B., Claridge, G.G.C., Balks, M.R. \& Campbell, D.I. 1997. Moisture content in soils of the McMurdo Sound and Dry Valley region of Antarctica. In Lyons, W.B., Howard-Williams, C. \& Hawes, I., eds. Ecosystem processes in Antarctic ice-free landscapes. Rotterdam: Balkema, 61-76.

Cannone, N., Wagner, D., Hubberten, H.W. \& Guglielmin, M. 2008. Biotic and abiotic factors influencing soil properties across a latitudinal gradient in Victoria Land, Antarctica. Geoderma, 144, 50-65.

Doran, P.T., McKay, C.P., Fountain, A.G., Nylen, T., McKnight, D.M., JAROS, C. \& BARETT, J.E. 2008. Hydrologic response to extreme warm and cold summers in the McMurdo Dry Valleys, East Antarctica. Antarctic Science, 20, 499-509.

Fountain, A.G., Hylen, T.H., Monaghan, A., Basagic, H.J. \& Bromwich, D. 2009. Snow in the McMurdo Dry Valleys, Antarctica. International Journal of Climatology, 10.1002/joc.1933

Gooseff, M.N., Barrett, J.E., Doran, P.T., Fountain, A.G., Lyons, W.B., Porazinsk, D.L., Virginia, R.A. \& Wall, D.H. 2003. Snow-patch influence on soil biogeochemical processes and invertebrate distribution in the McMurdo Dry Valleys, Antarctica. Arctic, Antarctic, and Alpine Research, 35, 91-99.

Hagedorn, B., Sletten, R.S. \& Hallet, B. 2007. Sublimation and ice condensation in hyperarid soils: modeling results using field data from Victoria Valley, Antarctica. Journal of Geophysical Research, 112, 10.1029/2006JF000580. 
Hagedorn, B., Sletten, R.S., Hallet, B., McTigue, D.F. \& Steig, E.J. 2010. Ground ice recharge via brine transport in frozen soils in Victoria Valley, Antarctica: insights from modeling $\delta^{18} \mathrm{O}$ and $\delta \mathrm{D}$ profiles. Geochimica et Cosmochimica Acta, 74, 435-448.

JuRY, W.A., Gardner, W.R. \& Garnder, W.H. 1991. Soil physics, 5th ed. New York: John Wiley \& Sons, 352 pp.

Kelleners, T.J., Ferre-Pikal, E.S., SchaAp, M.G. \& Paige, G.B. 2009. Calibration of hydra impedance probes using electric circuit theory. Soil Science Society of America Journal, 73, 453-465.

Lundin, L.-C. \& Johnsson, H. 1994. Ion dynamics of a freezing soil monitored in situ by time domain reflectometry. Water Resources Research, 30, 3471-3478.

Michalski, G., Bockheim, J.G., Kendall, C. \& Thiemens, M. 2005. Isotopic composition of Antarctica Dry Valley nitrate: implications for NOy sources and cycling in Antarctica. Geophysical Research Letters, 32, 10.1029/2004GL022121.

SAUER, T.J. \& LogSdon, S.D. 2002. Hydraulic and physical properties of stony soils in a small watershed. Soil Science Society of America Journal, 66, 1947-1956.
Seyfried, M.S., Grant, L.E., Du, E. \& Humes, K. 2005. Dielectric loss and calibration of the hydra probe soil water sensor. Vadose Zone Journal, 4, 1070-1079.

Soll SuRvey StafF 2006. Keys to soil taxonomy, 10th ed. Washington, DC: United States Department of Agriculture, Natural Resources Conservation Service, $331 \mathrm{pp}$. [Available online at http://soils.usda. gov/technical/classification/tax_keys/]

SPAANS, E.J.A. \& BAKER, J.M. 1996. The soil freezing characteristic: its measurement and similarity to the soil moisture characteristic. Soil Science Society of America Journal, 60, 13-19.

STEVENs 2007. The hydra probe soil sensor: comprehensive Stevens hydra probe users manual. Beaverton, OR: Stevens Water Monitoring Systems, 63 pp.

STEVENS Vitel 1994. Hydra soil moisture probe user's manual. Version 1.2 Chantilly, VA: Stevens Vitel, 22 pp.

Witherow, R.A., Lyons, W.B., Bertler, N.A.N., Welch, K.A., Mayewski, P.A., Sneed, S.B., Nylen, T., Handley, M.J. \& Fountain, A. 2006. The Aeolian flux of calcium, chloride and nitrate to the McMurdo Dry Valleys landscape: evidence from snow pit analysis. Antarctic Science, 18, 497-505.

\section{Appendix A. Soil profile descriptions}

\begin{tabular}{ll}
\hline Depth & Soil description \\
$(\mathrm{cm})$ &
\end{tabular}

\section{Wright Valley} $0-3$

$3-12$

$12-18$

$18-28$

$28-38$

$38-51$

$51-78$

78-109

109-130

Victoria Valley

$0-2$

$2-8$

$8-40$

$40-120+$

Marble Point 0-3

$3-15$
Light brownish grey (10 YR 6/2) very gravelly sand, very dark greyish brown (10 YR 3/2) moist; single grained; loose, loose, non-cemented, non-sticky and non-plastic; slightly effervescent throughout $(\mathrm{HCl}, 1$ normal); abrupt smooth boundary.

Brown (10 YR 5/3) silt loam, brown (10 YR 4/3) moist; slightly hard, very friable, non-cemented, brittle, non-sticky and non-plastic; slightly effervescent throughout $(\mathrm{HCl}, 1$ normal); abrupt irregular boundary.

Light grey (10 YR 7/2) silt loam, brown (10 YR 5/3) moist; massive and single grain; slightly hard, loose, non-cemented, brittle, non-sticky and non-plastic; slightly effervescent throughout $(\mathrm{HCl}, 1$ normal); clear smooth boundary.

Light grey (10 YR 7/2) silt loam, dark greyish brown (10 YR 4/2) moist; massive and single grain; slightly hard, loose, non-cemented, brittle. Non-sticky and non-plastic; slightly effervescent throughout ( $\mathrm{HCl}, 1$ normal); clear smooth boundary.

Very pale brown (10 YR 7/3) silt loam, brown (10 YR 4/3) moist; massive and single grain; slightly hard, loose, non-cemented, brittle, non-sticky and non-plastic; slightly effervescent throughout ( $\mathrm{HCl}, 1$ normal); clear smooth boundary.

Light brownish grey (10 YR 6/2) silt loam, brown (10 YR 5/3) moist; massive and single grain; slightly hard, loose, non-cemented, brittle, non-sticky and non-plastic; slightly effervescent throughout ( $\mathrm{HCl}, 1$ normal); clear smooth boundary.

Light brownish grey (10 YR 6/2) silt loam, brown (10 YR 5/3) moist; massive and single grain; slightly hard, loose, non-cemented, brittle, non-sticky and non-plastic; slightly effervescent throughout ( $\mathrm{HCl}, 1$ normal); clear smooth boundary.

Very pale brown (10 YR 7/3) gravelly silt loam, brown (10 YR 4/3) moist; massive; slightly hard, loose, non-cemented, brittle, non-sticky and non-plastic; slightly effervescent throughout (HCL, 1 normal); clear smooth boundary.

Light grey (10 YR 7/2) gravelly silt loam, greyish brown (10 YR 5/2) moist; massive and single grain; slightly hard, loose, noncemented, brittle, non-sticky and non-plastic; strongly effervescent throughout ( $\mathrm{HCl}, 1$ normal).

Desert pavement, weakly weathered (10 YR 7/2 dry, 10 YR 5/2 wet), gravelly sand, (estimate $70 \%$ gravel, $30 \%$ sand), colours of individual grains are evident, occasional thin $(<0.5 \mathrm{~mm})$ intermittent salt accumulations on base of stones, $<1 \%$ moisture, distinct smooth boundary. Weakly cemented (10 YR 7/2 dry, 10 YR 5/2 wet) gravelly sand (estimate 20\% gravel, $77 \%$ sand, 3\% silt), gravels are predominantly $1-50 \mathrm{~mm}$ in diameter, weakly weathered, sub-angular, cementation is sufficient to hold an overhang of up to $20 \mathrm{~cm}, 2 \%$ moisture, distinct smooth boundary.

Unweathered, stratified gravelly sand (estimate $20 \%$ gravel, $77 \%$ sand, $3 \%$ silt), gravels are predominantly $10-50$ mm in diameter, weakly weathered, sub-angular. Colours are those of individual sand grains and range from dark grey to white, occasional pebble layer is evidence of former surface horizon, $2 \%$ moisture, sharp smooth boundary.

Ice-cemented material essentially similar to the horizon above as evidence by drill holes to install MRC probe.

Dark greyish brown (10 YR 4/2) very gravelly sand, very dark greyish brown (10 YR 3/2) moist; single grain; loose, non-cemented, non-smeary, low toughness, non-sticky and non-plastic; strongly effervescent throughout ( $\mathrm{HCl}, 1$ normal); $1 \%$ marble cobbles and $1 \%$ gneiss cobbles and $1 \%$ igneous-granite cobbles; clear smooth boundary.

Brown (10 YR 4/2) very gravelly sand, dark brown (10 YR 3/3) moist; strong single grain; loose, loose, non-cemented, non-smeary, low toughness, non-sticky, and non-plastic; very slightly effervescent throughout ( $\mathrm{HCl}, 1$ normal); $1 \%$ marble cobbles and $1 \%$ gneiss cobbles; clear smooth boundary. 
Appendix A. Continued

\begin{tabular}{|c|c|}
\hline $\begin{array}{l}\text { Depth } \\
\text { (cm) }\end{array}$ & Soil description \\
\hline $15-32$ & $\begin{array}{l}\text { Brown (10 YR } 5 / 3) \text { very gravelly sand, dark brown (10 YR } 3 / 3) \text { moist; strong single grain; loose, loose, non-cemented, non-smeary, } \\
\text { low toughness, non-sticky and non-plastic; slightly effervescent throughout ( } \mathrm{HCl}, 1 \text { normal); } 1 \% \text { marble cobbles and } 1 \% \text { gneiss } \\
\text { cobbles and } 1 \% \text { igneous-granite cobbles; clear smooth boundary. }\end{array}$ \\
\hline $32-45$ & $\begin{array}{l}\text { Greyish brown ( } 10 \text { YR } 5 / 2) \text { very gravelly sand, dark brown }(10 \text { YR } 3 / 3) \text { moist; strong single grain; loose, loose, non-cemented, non- } \\
\text { smeary, low toughness, non-sticky and non-plastic; strongly effervescent throughout (HCL, } 1 \text { normal); } 1 \% \text { marble cobbles and } 1 \% \\
\text { gneiss cobbles and } 1 \% \text { igneous-granite cobbles; clear smooth boundary. }\end{array}$ \\
\hline $69-100$ & $1 \%$ marble cobbles. \\
\hline
\end{tabular}

Scott Base

0-1

$1-7$

15-30

Minna Bluff 0-4

60-80+

Granite Harbour 0-2

80-90+

Mount Fleming 0-2
Greyish brown (10 YR 5/2) gravelly sandy loam, very dark greyish brown (10 YR 3/2) moist; moderate fine and medium lenticular platy and single grain; soft, very friable, non-sticky and non-plastic; non-effervescent ( $\mathrm{HCl}, 1$ normal); 30\% angular basaltic-ash gravel; abrupt smooth boundary.

Pale brown (10 YR 6/3) gravelly sandy loam, very dark greyish brown (10 YR 3/2) moist; moderate very fine and fine single grain; loose, loose, non-sticky and non-plastic; non-effervescent ( $\mathrm{HCl}, 1$ normal); 30\% angular basaltic-ash gravel; clear smooth boundary.

Brown (10 YR 5/3) gravelly sandy loam, dark greyish brown (10 YR 4/2) moist; moderate very fine and fine single grain; loose, loose, non-sticky and non-plastic; non-effervescent ( $\mathrm{HCl}, 1$ normal); $35 \%$ angular basaltic-ash gravel; clear smooth boundary. Brown (10 YR 5/3) gravelly sandy loam, brown (10 YR 4/3) moist; moderate very fine and fine single grain; loose, loose, non-sticky and non-plastic; non-effervescent ( $\mathrm{HCl}, 1$ normal); 35\% angular basaltic-ash gravel; abrupt smooth boundary.

Desert pavement. Gravelly coarse sand, colours are those of individual mineral grains, dry, salt accumulation beneath some rocks (1 sample). The desert pavement comprised dominantly basalts and dolerites, including scoreacious and porphoritic basalts. Granites (pink, red, grey and white dominated) were common with a range of other rock types seen occasionally including Beacon sandstone, weathered marble, angular conglomerates and shale. The pavement materials were generally moderately rounded and smooth, a few with desert varnishing. (Generally more weathered than Marble point). The pavement comprised about $5 \%$ large boulders ( $>30 \mathrm{~cm}$ diameter), $10 \%$ medium boulders $(20-30 \mathrm{~cm}$ diameter), $20 \%$ stones $(5-20 \mathrm{~cm}$ diameter) and remainder gravel and coarse sand. Distinct, smooth boundary.

Brown (10 YR 4/4) gravelly loamy sand (estimate $2 \%$ silt and clay in $<2 \mathrm{~mm}$ fraction), moisture content of $<2 \mathrm{~mm}$ fraction was $15 \%$, loose, gravel content variable - ranging from about 30 to $70 \%$, no salts seen, diffuse boundary.

Dark brown (10 YR 3/3) gravelly loamy sand (estimate $2 \%$ silt and clay in $<2 \mathrm{~mm}$ fraction), slightly moist $(<2 \mathrm{~mm}$ fraction was $10 \%$ ), very loose, gravel content variable - ranging from about 30 to $70 \%$, measured as $64 \%$ by weight $>5.6 \mathrm{~mm}, 17 \%$ by weight $2.6-2 \mathrm{~mm}$ and $19 \%<2 \mathrm{~mm}$, no salts seen, sharp smooth boundary.

Dull yellowish brown (10 YR 4/3) gravelly icy sandy silt loam (estimate $60 \%$ silt and $10 \%$ clay in $<2 \mathrm{~mm}$ fraction), ice saturated $(>50 \%$ ice), ice-cemented, very sticky when melted, gravel content about $30 \%$, boulders about $1 \%$, no salts seen, diffuse smooth boundary. Greyish yellow brown (10 YR 4/2) gravelly icy sandy silt loam (estimate $60 \%$ silt and $10 \%$ clay in $<2 \mathrm{~mm}$ fraction), ice saturated ( $>50 \%$ ice), ice-cemented, very sticky when melted, gravel content about $10 \%$, boulders about $1 \%$, no salts seen

Desert pavement comprises about $50 \%$ granite boulders greater than $80 \mathrm{~cm}$ diameter, some up to $5 \mathrm{~m}$ in diameter, $30 \%$ granite boulders and stones of less than $80 \mathrm{~cm}$ diameter, $10 \%$ sand and $10 \%$ granite gravel. Boulders are rounded and weathering by grains falling off. A small amount of iron oxidation is visible on some boulders. The matrix is gravelly coarse sand which comprises angular mineral grains from the granite, colours are those of individual minerals, minimal chemical weathering, dry, loose, distinct smooth boundary.

Dull yellowish brown (10 YR 5/4 dry, 10 YR 4/4 moist) gravelly coarse sand which comprises rounded mineral grains from granite, moderately weathered with a trace $(<1 \%)$ of silt and clay and some iron oxides, dry loose, no salts seen, diffuse smooth boundary. gravelly coarse angular sand, minimal chemical weathering, colours are those of granite minerals (pink, white, grey, black), loose, dry, no salts seen, distinct wavy $( \pm 10 \mathrm{~cm})$ boundary.

Dull yellowish brown (10 YR 4/3) loamy fine sand, sand is very uniform and well sorted, and does not have the individual granite minerals obvious (maybe a beach deposit?) moist, firm in situ (holds vertical walls in pit), few angular stones (about $10 \%$ ), few granite gravels (about $5 \%$ ), occasional lenses of coarse granite sand (ghosts of boulders), irregular distinct boundary.

Gravelly coarse sand, 70\% strongly interlocking stones and boulders, sand is unweathered granite mineral grains in granite mineral colours, this horizon is interpreted as a buried former desert pavement, indistinct irregular boundary.

Ice-cemented sands with many rocks.

Desert pavement, very strongly weathered, polished and pitted boulders and gravels with (10 YR 6/3 dry, 10 YR 5/4 moist) coarse sand, surface boulders cover about $60 \%$ of surface, are up to $1 \mathrm{~m}$ in diameter, and have strong desert varnish and ventifaction. Dolerite is dominant with sandstone and granite also present; gravels are sub-angular, desert varnished, many ventifacted, dolerite and quartz dominate, sands are coarse, loose and weathered to $\mathrm{FeO}$ colours, about $\%$ moisture, distinct irregular boundary. 
Appendix A. Continued

Depth Soil description

$(\mathrm{cm})$

$2-8$

Strongly weathered bouldery gravelly, (10 YR 6/6 dry, 10 YR 5/4 moist) coarse sand (estimate 98\% sand, 2\% silt), common $0.5-0.8 \mathrm{~cm}$ thick, white, salt crusts under larger stones. About $20 \% 10-40 \mathrm{~cm}$ diameter boulders, angular, some strongly weathered (so fall apart when disturbed), dolerite dominant, but granite and sandstone also present. About $30 \%$ gravels, angular (rocks split to gravel size), weakly to strongly weathered, dolerite dominant with granite, sandstone and some rounded quartz pebbles, about $7 \%$ moisture (following recent snow), distinct, irregular boundary.

Weakly weathered gravelly ( 2.5 Y $7 / 2$ dry, 2.5 Y 5/2 moist) silty sand (estimate $70 \%$ fine sand, $30 \%$ silt), no salts visible, about $10 \%$ unweathered angular gravel, with an occasional (10\%) up to $20 \mathrm{~cm}$ diameter, non to weakly weathered, angular boulder, about $5 \%$ moisture, diffuse, smooth boundary.

Relatively unweathered gravelly ( 2.5 Y 6/2 dry, 2.5 Y 4/2 moist) silty sand. About $10 \%$ unweathered, angular gravel and rocks, about $2 \%$ moisture, sharp distinct boundary.

45-70 Ice-cemented ground, similar material to the horizon above, but with sufficient water to cement (16\% moisture, sample appeared to be saturated when thawed) $(2.5$ Y $5 / 1$ wet $)$. 